\title{
Conversion and Memory: A Dialogic Narrative Contextualisation of Liminal Identity
}

\author{
Katica Kulavkova, PhD \\ Macedonian Academy of Sciences and Arts (MASA), \\ Republic of Macedonia \\ Jasmina Ilievska-Marjanovic, BA \\ Independent Researcher, Republic of Macedonia
}

\begin{abstract}
Ethnic and religious conversion is deeply engraved in the history and memory of the Macedonian people, yet it remains a painful taboo subject. The paper is interested in the treatment of this topic in the New Macedonian Novel, which brought this problem from the collective unconscious into the public dialogue and shed light on its reoccurrence today. The analysis focuses on the novel The Book of Heavens (2000) by Krste Chachanski since it is equally representative of the topic of conversion to Islam in the Ottoman past, the poetics of the New Macedonian Novel, and the Macedonian dialogic and liminal identity. The Book of Heavens is set at the end of the 18th century in mountainous Macedonia, the forsaken Balkan periphery of the Ottoman Empire. It is centred around Adnan Pasha, the bi-religious and bi-cultural Janissary from Macedonia, his internal turmoil, and his quest for becoming the ethical warrior of his wilful choosing. The novel is a meta-historical and multi-voiced parable of dialogism and liminality in the context of human cognition, identity, and culture. But it is also a mythopoetic and magical realist saga for the ethical warrior, for the Macedonian tragically split and persecuted identity, for the syncretic civilisational borders and peripheries, and for protecting the palimpsest memory of human culture. The literaryhermeneutical analysis of conversion in this paper is inevitably a form of cultural and methodological syncretism. Self-plurality psychology and the linguistic, semiotic, and cultural philosophies of Bakhtin, Lotman, Ricoeur, and Eco are used in the analysis.
\end{abstract}

Keywords: Macedonian identity and cultural memory, Dialogism and Selfplurality, Ottomanisation and Janissaries, Macedonian New Novel, The Book of Heavens by Krste Chachanski 
'Such a dialogic encounter of two cultures does not result in merging or mixing. Each retains its own unity and open totality, but they are mutually enriched.'

(Bakhtin, 1986, 7)

\section{Introduction and narrative theory terminology:}

The end of the twentieth century and the beginning of the twenty-first was a flourishing time for the Macedonian novel regarding its production and its subgenre poetics and stylistics. In a short period, ten significant novels were published by authors belonging to different generations. These authors with divergent biographies, values, and acclaim created works that now delineate an entirely new novelistic poetics within Macedonian literature. Namely, the New Macedonian Novel was being created.

The main interest in this paper is the treatment of the topic of religious and ethnic conversion in the New Macedonian Novel. Therefore, the characteristics of this new novelistic paradigm will not be examined explicitly. Yet, while speaking of conversion, the paper will implicitly address the following characteristics of the New Macedonian novel:

- multiplication of the novel's narrative;

- narrative mise-en-abîme (a story within a story, a novel within a novel);

- abandoning the poetics of linear narration;

- multifocal narration (narration from various points of view);

- ostensible ludism and improvisation;

- enigmaticity;

- autoreferentiality;

- fictional perfectionism;

- metanarrative playfulness (reflections that the text makes on its nature) and historiographic metafiction (the novel is a response to the historiographic and literary narratives);

- feigning facts and pseudo-quoting history;

- fictional sophistication of the biographic discourse;

- dosing the difference between fiction and reality;

- the actualisation of collective traumas;

- illusion as an allusion to reality (for instance, using the illusion of the past to allude to the present);

- revision of ethical codices;

- revision of genre conventions;

- mixing the highbrow with the lowbrow colloquial styles;

- a grotesque image of the world;

- a communicative interest for the reader and a wider/mass audience;

- trivialisation of the novel; 
- the actualisation of the archaic linguistic matrices of the Macedonian language;

- heteroglossia and dialogism;

- 'double coding'-high and low code (the artistic literary work is intentionally double coded to address both the elite readership and the mass reading public); and

- intertextual irony (triple coding), which - due to an absent verifiable source - enhances the ambiguity of the literary statement.

Self-plurality psychology and the linguistic, semiotic, and cultural philosophies of Mikhail Bakhtin, Juri Lotman, Paul Ricoeur, and Umberto Eco will be used in the interpretation. Cultural hermeneutics will be used in the literary analysis since the researchers share the view that poetics is in synergy with culture and that the analysis of a novel's poetics is not possible if the cultural implications are excluded from the reading. Literary hermeneutics today 'cross-breeds' the poetic and the culturological methods, creating an open and interdisciplinary methodological syncretism. The lead author of this paper postulated 'Interpretative Syncretism' as an interpretative approach/methodology/strategy in the interpretation of works of literature.

\section{Conversion in the New Macedonian Novel:}

There are several important aspects of the phenomenon of conversion that are specific for the Macedonian context and for its role in the Macedonian New Novel.

First of all, the actualisation of the theme of religious, ethnic and linguistic conversion in the genre of the novel is an allusion to its deeply enrooted praxis in the memory of a people. Conversion has been constantly present in Macedonian history, but it has different manifestations throughout different eras. The conversions that happened during the Ottoman rule in Macedonia will be of special interest to us in this paper. During the Ottoman Era, conversion had specific characteristics because it took place within circumstances when ethnicity was postulated as a manifestation of religious affiliation and it became a key social factor. Thus, it needs to be interpreted not only from the standpoint of individual reactions and conditions but also as a socio-cultural phenomenon. Inside the Ottoman Empire, a few different forms of conversion were practiced: Janissary, ${ }^{1}$ violent, voluntary, collective,

\footnotetext{
${ }^{1}$ Translator's Note (TN): The Janissaries (in Turkish, Yeniçeri, which means 'new soldier', 'new troop') were the elite infantry units that formed the household troops of the Ottoman Sultan from the late 14th century to 1826 . They were the Sultan's own bodyguards, privileged and highly respected for their military prowess, because they were subject to strict rules and highly trained since early childhood, even though they were staffed by abducted children from the conquered Christian territories in the Balkan provinces who were forcefully converted to Islam and drafted into the Ottoman military service. This method of recruitment of the
} 
and individual conversions. The methods of Islamisation of the Christian and non-Muslim population primarily contain elements of a systematically conceived economic pressure, but do not entirely exclude other forms of forced Islamisation: Janissary, decrees for collective conversions to Islam, destruction of churches, book burning (for instance, in the monastery St. Mother of God in the village of Slivnica, Prespa region, in the 18th century), and other forms of terror. Yet, this gamut of conversion models also includes the self-initiated individual conversion.

Secondly, the conversion is only seemingly a detached and partial phenomenon, but in essence, it is an all-encompassing social phenomenon with cultural, political, psychological, ethnological, and anthropological implications. It destroys one personal and ethnocultural identity to establish another. The identity of the convert is dual and unstable, particularly during the phase of its founding. So, by bringing up the theme of conversion, the New Macedonian Novel sheds light on the dual and split identity of the Macedonian man in the delicate Macedonian and Balkan circumstances. The researchers would describe these delicate social circumstances in the following way: a clash of interests; territorial crossovers; disproportional state founding processes; an absence of indifference (not only in the Balkans, but also among the influential European states); interventions of the powers that be in the key peace negotiations and agreements whenever their interests are to be articulated; a discrepancy between state and ethnic borders; ethnic, religious, and linguistic co-existing within the great empires, followed by more or less violent assimilation projects of conversion and migration; and an absence of state institutions that would protect the Macedonian national and ethnic interest, apart from the Ohrid Archbishopric in the period between the tenth and the eighteenth century. In spite of being biased by his nation's political agenda, the British journalist Henry Noel Brailsford explains exactly how religion, ethnicity, and national identity became interwoven during the Ottoman rule in Macedonia and the Balkans. He points to the political circumstances which made the Orthodox Church the only legal national organisation in the Ottoman Empire for five centuries:

It is not so much the religious instincts of the Balkan peasant as his political conditions which explain his passionate attachment to his Church and the great part which it plays in his existence. His fidelity to his Church has been through five centuries one continuous martyrdom. He has remained true to it not merely from a reasoned or traditional faith in its tenets, but rather because apostasy involved a foreswearing of his nationality and a treason to the cause of his own

Janissaries was known among the non-Muslim subjects as 'the blood tax' [in Turkish it was called Devşirme, 'collection'], and it lasted until the 18th century. (The Editors of Encyclopaedia Britannica, 2014) 
race. It is the only free and communal life which the Turks permit him. It is essentially a national organisation. It reminds him of the greater past. It unites him to his fellow-Christians throughout the Empire, and in the free lands beyond the Empire. It is the one form of association and combination which is not treasonable. Its Bishops are the sole Christian aristocracy in Turkey, its synods and its local councils the only form of autonomy or representative self-government which the law allows. [...] This transformation of the Orthodox Church into a national organisation was a consequence of the peculiar civilisation of its conquerors. The Turks were a military people with a theocratic organisation. Their law was a religious code; their army a force which conquered in the name of a faith. Of civil law and civil administration they had no conception [...] Disputes among Christians were left to the Christian Church for settlement, and the heads of the Church were made responsible to the Ottoman officials for the good government of their flocks. Society was organised in Churches, to one or other of which every Ottoman subject must belong. These Millets, as they are called-Islam, the Greek Church (Roum), the Catholics, the Armenians, and the Jews - were the only subdivisions which the Turks recognised. (2002, 118 [1906, 61-2])

Thirdly, the novelistic actualisation of conversion in the New Macedonian Novel is a sign that this is a despairing and painful theme. This is a theme that has not been fully understood, at least not yet. It is a theme that is still mystified and suppressed within the realms of the collective and individual subconscious, so it is still a latent source of new collective obsessions and traumas. The British historian Eric Hobsbawm states that religious identity, including religious conversion, was and still is a factor for national identities and nationalism (1990, 12-3). And, the Serbian historian Bojan Aleksov writes the following about conversions on the Balkans:

Ever since the sixteenth century, one can verifiably follow religious intolerance in the Balkans, since that is when the first mass encounters and confrontations among the religiously divided Slavic population happened. Around then, more and more explicitly, by setting up military borders across the South Slavic ethnic territories, war was coming down to mutual confrontations of members of the same people, divided by religion and imperial borders (Aleksov, 2006, 227) [...] in this way, the myth of religious conversion became a paradigm, or a systematic reference, for any kind of disagreement and resistance to the 'national' imperatives. The most tragic consequence of these stereotypical representations of conversion was the constructed 
stereotype about the character of the convert, which was later used to label entire nationalities. (Aleksov, 2006, 258). ${ }^{2}$

And finally, there is no such thing as a bias-free memory. The things that leave people completely indifferent can easily be dismissed or forgotten. But memory implies an emotional attitude, being concerned, and being affected by the world/the ' $\pi \rho \alpha \gamma^{\prime} \mu \alpha \tau \alpha$ ' (the objects, the entities, the things), which is especially articulated in the novelistic literary production. Here are several examples from Krste Chachanski's The Book of Heavens [Kniga na neboto] (2000) to illustrate this emotional bias related to the memory of conversion in this representative novel:

'You see me with a knife slung through the eye' (13);

'The body of the story is the living infidelity itself in a female form, and at nightfall, she starts her journey through the villages' (243);

'the body of the fear falls asleep in one language, and wakes up in another; it is the distance between life and story' (46);

'they mourned in Macedonian' (175);

'he passed through her as a ravaging storm' (50);

'his voice was a violet-tinted air that flickers in the summer heat' (56); 'When the churches were demolished and mosques placed in their stead, the people of Drimeni, Ortakol, and Lundzani went numb. When they finally started to speak again, their language resembled the 'local springs', the chieftains' (129);

'The grand idea of Adnan Pasha_that is, of George [Gjorgjija]-for freedom of his people was a hope that never died, but only kept quiet and hidden for a century or two, it was only waiting in ambush, laying down in the stories, from there taking aim through the minds and hearts of many' (130-131). ${ }^{3}$

Furthermore, the interpretation of conversion in the New Macedonian Novel is culturally contextualised in the present, analogous to the very phenomenon of conversion itself. The created novelistic illusion on the subject of the traumatic past experiences of conversion becomes an allusion to the dramatic experiences in the present (the illusion becomes an allusion). Therefore, the hermeneutics of the novel is transformed into a hermeneutics of the history and the memory of a people. The Macedonian novel is the consciousness and the conscience of Macedonian identity.

From the perspective of literary history, conversion is a theme that has been either entirely absent or only simplistically represented in the Macedonian novel for quite some time (Kulavkova, 2000, 295-310). There was only the paradigm created in the 1950s by Stale Popov (1902-1965), who

${ }^{2} \mathrm{TN}$ : translated here into English from the Serbian original.

${ }^{3} \mathrm{TN}$ : In this paper, all citation from Krste Chachanski's The Book of Heavens is translated into English from the Macedonian original. 
had created an excellent model for the realist novel. However, the poetics of the realist novel and the dominant worldview of the time did not allow a heteroglossic reading of the conversion of Christians into the Islamic faith. The renewed interest for this theme in the novels Babadjan by Zhivko Chingo (1935-1987) and A Change of Gods [Promena na Boga] by Slobodan Mickovic (1935-2002), published in 1989 and 1998, respectively, heralded the change in the Macedonian novelistic paradigm, not only in regard to the theme, but also with respect to its poetics. It signalled a change in the national perception of this socio-cultural phenomenon, anticipating some of the contemporary forms of conversion within Macedonian society.

The New Macedonian Novel presents exceptional examples that depict a perceptive interest in the Islamisation and the Turkification of the nonMuslim population (including Christians) that lived on Macedonian territory during the Ottoman Empire: Macedonians (Macedonian Slavs or Slavic Macedonians), Bulgarians, Aromanians, Armenians, Jews, and others. In these novels, the Ottoman Era (rule and culture) is depicted through the prism of the subject of religious conversion, who is simultaneously the subject of ethnic and linguistic conversion. The Ottoman Era was notably governed by the practice of identifying ethnic affiliation with religious affiliation, thus forming the relatively autonomous administrative category millet that was based on ethnoreligious principle. By bringing up this topic, the topos of Macedonian convertism was transferred from the realm of taboos and collective amnesia into the realm of cultural dialogue and collective awareness. With that, the New Macedonian Novel was suggesting a complex scientific and social dialogue on the theme of conversion, a dialogue which needs to be continued in a comparative manner in the Macedonian and Balkan scientific milieu today.

The period around the year 2000 is quite indicative for the problem of conversion in Macedonian literature, as it sees the publication of three new and exceptional representative examples of the Macedonian New Novel, even though these novels were almost unnoticed by the literary critics at that time: Krste Chachanski's The Book of Heavens [Kniga na neboto] (2000), Olivera Nikolova's Variations on Ibn Pajko [Vežbi za Ibn Pajko] (2001), and Dragi Mihajlovski's The Death of the Wild One [Smrtta na dijakot] (2002). These three slim volumes focus on the problem of conversions, a problem which mobilises not only the aspect surrounding the conflict between the various ethnic and religious identities, but also the aspect surrounding the linguistic, religious, and ethnic co-existence within the Ottoman Empire. They, in fact, actualise rather than revise the stereotypes of the Balkans as a 'powder keg' and 'honey and blood', i.e., of Macedonia as the 'Balkans on a small-scale', as the 'tower of Babel' of different languages, or even as a 'mixed salad', popularly 
speaking (Kulavkova, 2006a). Here are some examples of this from Chachanski's The Book of Heavens:

Drank! Earth-earth, earth-earth, they are digging out rocks, rocksrocks, tombstones, old cemetery tombstones, cemeteries, cemeteries, skeletons and skulls, skulls, skulls! Fucking Balkans! (14)

This is the Balkans! Split it in half, break it in two. 'Bal' is honey, 'kan' is blood. Honey and blood! (17)

This is the Balkans! The first thing they'll try to blow up to smithereens will be this castle right here! Your Chambord castle! They'll object to its size, its beauty, to your power! (22)

The novel Variations on Ibn Pajko by Olivera Nikolova (b. 1936) is an interesting identity reconstruction game about the patron mason builder of Pajko's Mosque in Skopje. He is called Ibn Pajko, which means the Son of Pajko. But Pajko's name could also have been Tajko, Bajko, Marko, Sandri, or Petre, which points to the various possibilities of his ethnic background. This Rashomonesquely open reconstruction of his identity turns into a reconstruction of the identity of converts and of conversion in Macedonia at the end of the fifteenth and the beginning of the sixteenth century. Still, the novel happens in a kind of a meta-historical in-between time that is a cross between the real and the imaginary. And it is placed within the framework of the chronotope of the city of Skopje, which is represented as a prototype of the Balkan chronotope. In spite of its complementarity to Chachanski's novel, this novel is more suitable for a comparativist interpretation of the many Balkan identities in Macedonia, so it will be left for a different occasion when the focus would be on this type of interpretative contextualisation.

The novel The Death of the Wild One by Dragi Mihalovski (b. 1951) gravitates towards the novels by Chachanski and Nikolova in terms of its interest in the Ottoman Era, but here the conversion is not semantically dominant. The novel takes place during the days of the fall and raid of the city of Bitola at the end of the fourteenth century. It depicts three conflicting visions of the world, which are embodied through the three narrators: the subjugated Ravul, the subjugator Timurtash, and the devil Velzevut. As a result, what prevails in this novel are historiographic metafiction, simultaneity, and dispersion of the triple narration: the narratives of the two believers (the Christian and the Muslim one) and the third narrative of the unfaithful and diabolic subject (Satan himself). So, a more integral interpretation of this novel will also be postponed for a different interpretative occasion.

The main analysis and the illustrative material of his paper will be based on the novel The Book of Heavens by Krste Chachanski (1949-2003). Chachanski's previous two novels, God's Dream [Bozhjiot son] from 1994 and The Shadow of the Bat [Senkata na liljakot] from 1997, will also not be 
covered here due to their different contextualisations.

\section{The narrative techniques used in Krste Chachanski's The Book of Heavens:}

As a novel, Krste Chachanski's The Book of Heavens (2000), is equally paradigmatic both for the poetics of the New Macedonian Novel and for the topos of conversion of religious, ethnic, and linguistic identities in Macedonia. If the lead author were allowed the freedom to begin the interpretation with an interpretative heresy - namely to rate the quality of the work before analysing it - this analysis would start with the critical evaluation that this novel is one of the most harmonious of Macedonian novels in terms of narrative, one of the subtlest in terms of conveying meaning, and one of the most soul-stirring in terms of its 'arrangement of incidents'. ${ }^{4}$ As this paper will demonstrate, Chachanski's novel is paradigmatic for the theme of conversion of identities, since his methodology of observing the historical reality does not 'frame the composition of the shot' in kitschy ideological frames when depicting conversion; rather, it depicts it in all of its ethnic, ethical, and aesthetic complexity, showing its paradoxical essence. Therefore, the novel The Book of Heavens (along with Variations on Ibn Pajko) has gained the status of a reference point in the interpretation of Macedonian history and Macedonian identity. This novel suggests that it is necessary to open the written and unwritten archives of Macedonian history, so as to enable the praxis of conversions to become an inalienable part of human history.

First of all, Chachanski's novel renders the topic of conversion through the narrative technique of metanarration. This technique is a key feature of the Macedonian New Novel and all of its mentioned characteristics organically stem from it. Historically viewed, metanarration has been instrumentalised as a conscious narrative technique within postmodernist prose, but its origins are, in fact, ancient. According to Umberto Eco (2002, 198), even Homer's epic The Iliad is metanarrative, since the epic narrator/singer/rhapsod says 'Sing, $\mathrm{O}$ Goddess, the destructive wrath of Achilles' at its very beginning (Homer, Iliad 1.1). Chachanski's novel employs the tools of metanarration through quotes, pseudo-quotes, and metahistorical mystifications. At different places, quotes and/or pseudo-quotes are inserted, taken from the Sultan's decrees, census forms, and similar archival documentation. Several other texts have been inserted in the text of the empirical author Chachanski: the text of the scrivener [yazici], the text of Adnan Pasha, the quotations from folk poetry, and the

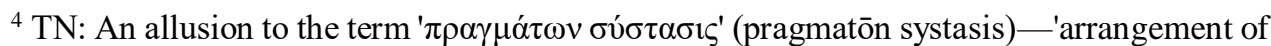
incidents' in the English translation by W.H. Fyfe (Aristotle, 1932, 1450a5), or 'composition of incidents, or things done in the story' in the previous translation by Ingram Bywater (Aristotle, 1920, 1450a5) — from Aristotle's Poetics, when defining the plot (the way/order in which the story is told) as the most important feature of tragedy as a genre. 
fragments from another book that is referred to as 'book of heavens'. So, within this metahistorical novel, there is another novel, a metaphysical one, that is also called the book of heavens. Within the lines of the first novel, one can read parts of the other one. This book of heavens is described as 'the book which tells it all', a book which 'narrates us' and 'narrates the Macedonian people', which at times alludes to the Holy Scriptures and a prophetic book of the truth (127):

'The book of heavens is buried in the words of any man in any language! It is the life of every man, individually! It is the destiny of us all!' (127)

'The book of heavens speaks about 'the futility of each endeavour.' (127)

'It is the genealogy book, the book of names, the book of destinies of each one of us individually, and of an entire nation. The genealogy of a people is the book of heavens.' (127)

From all these texts with different geneses a collage is created, whose mutual congruity produces the wholeness and the onticity of the novelistic world. ${ }^{5}$ Narration is only seemingly disintegrated, but essentially, it is whole.

Secondly, the novel is intentionally 'double-coded'. It relies on a certain degree of pre-knowledge from its readers, but at the same time, it is equally accessible for the less-informed readers. The Italian novelist and literary theorist Umberto Eco who, in today's postmodern 'age of lost innocence', openly discusses and employs 'double coding' in his writing, points out that this technique is also not postmodern but ancient. According to Eco, the literary masterpieces of Homer, Cervantes, and Shakespeare can be seen as 'double coded' as well. Along with their obvious belonging to the high-brow literary canon, they can also be observed as popular literature, based on how much they have been read throughout the centuries and on their many reprints and copies $(2002,197-8)$. The historical topos of Chachanski's novel is a part of the collective memory of the Macedonian people and a part of Balkan traditions, so it excludes indifference from the general public. But the novel follows the logic of meta-historiographic fiction (Currie, 2011), which means that it is not so much a depiction of a given historical reality, as it is a response to the already present interpretations of the historical reality. For instance, the novel responds in a meta-historiographic manner to the following: to the oral history tradition (through the bagpiper Pavle Ivano); to the written literary tradition tied to the church-monastic cultural code (through the scrivener); to the legacy of historical ancestors and of memories in the administrative discourse of archives (through the edicts, letters, census forms, and registers);

${ }^{5} \mathrm{TN}$ : In philosophy, 'onticity' is the quality of physical, real, or factual existence (from the term 'ontic', which comes from the Ancient Greek ôv, and its genitive oovtos: 'of that which is'). 
to the official historical narratives (through the 'grand narratives' that are endlessly being repeated, regardless of their validity); to the books with spiritual, sacral, and occult contents (The Book of Heavens and other similarly named titles in the novel); and to the well-known general references from Macedonian literature, like the verses 'The night is being forged! A stone wakes to it!' from Kosta Solev Racin's 1939 poem 'The Diggers' (Racin, 2018, 40). The novelistic world is comprised of numerous mosaic fragments that have been put together with a metonymical logic, although they are dramatic on the semantic level. In theory, this literary facet of poetisation does diminish the statement's plausibility as a realist value, yet it fundamentally increases its symbolic value for memory and memory's cultural function.

Thirdly, the novel alludes to the present with the narrative technique of intertextual irony. Here is how Umberto Eco writes on intertextual irony:

Intertextual irony provides an intertextual second sense for readers who have been secularized and who no longer have any spiritual senses to look for in the text. [...] The intertextual second sense is horizontal, labyrinthine, convoluted, and infinite, running from text to text - with no other promise than the continual murmuring of intertextuality. Intertextual irony presupposes an absolute immanentism. It provides revelations to those who have lost the sense of transcendence. (Eco, 2002, 218)

In this novel, conversion is shown in a personified manner as a concrete manifestation in concrete historical and metahistorical circumstances, but it instigates the illusion that it is a reconstruction of an archetype. The reconstruction of conversion in Chachanski's novel has the characteristics of a vision that not only evokes but also predicts and warns, by which it performs a significant social and ethnocultural function. Chachanski's novel is rereading the distant past through the lens of the not-so-distant past, but implicitly, he is interpreting the present through the lens of the past. It actualises some collective and poetic images about the spirit of the longsuffering people, which in turn ironically hint that the Macedonian reality has not changed significantly from one century to another. The intertextual allusions remind the reader that the night of enslavement for this people is a lengthy one and that the dawn of freedom has been announced time and again, but they ironically hint that the Macedonians seem to be experiencing a condition of an ontological sunrise. They are never quite in union with the night, nor free of the night. Therefore, the ontological sunrise itself may also be interpreted as ontological dusk.

Fourthly, the novel remains intensely autoreferential, formalist, and enigmatic, since it employs the narrative techniques of multiplication of narration, multifocality, and heteroglossia. The intertextual allusion, irony, and foretelling are carried out through a quiet dialogue between the writer and 
the reader This is a dialogue in which the interpretative intentions of the writer and of the reader cross paths only from time to time. All identification is accomplished in a diffused manner and in multiple directions, particularly concerning the various narrative subjects, their voice/language, their eye/worldview, and the way they are constructed in the novel. This diffusion of identities has a labyrinthine, rhizome-like, and ambiguous semantic structure, so it is easier to detect the narrative procedures than the story. And when writing about the reader, this paper aims at connecting Umberto Eco's two types of readers, namely the semantic reader and the semiotic reader (Eco, 2002, 206-7). The former is interested in what takes place in the novel, what the story is like and how it will end, whereas the latter is the aesthetic or critical reader who is continuously asking himself how the story is being told, what narrative techniques are being used in the novel, etc. Eco writes that in order to be the latter type of reader, one needs to re-read the novel a few times (Eco, 2002, 207), but in some novels, it is also necessary to re-read the novel a few times even to reconstruct the story. How else could one reconstruct the lost, de-chronologised, and enigmatic story of William Faulkner's As I Lay Dying and The Sound and the Fury, or of Virginia Woolf's Mrs. Dalloway and The Waves?! This is the case with Chachanski's novel as well! Several stories coexist in it, creating a multi-narrative, which persists through its complexity only because of its ambiguity; since its intention is not aimed at accomplishing a simplistic semantic reproduction, but rather to puzzle us with its enigmatic nature. The conversion texture has been impregnated here not only as an isolated historic proto-text, but also as a cultural intertext that is approached by a conscious attitude - distant enough to appear ironic, and partial enough to be individually and originally marked.

\section{The border chronotope and the liminal characters in Krste Chachanski's novel The Book of Heavens:}

In the analysis of Krste Chachanski's The Book of Heavens, one has to address its specific chronotope-the chronotope of the border-and the terminology related to it. This paper finds it to be crucial for its analysis.

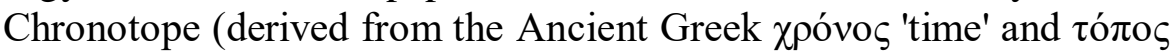
'space') is a term introduced in literary theory by the Russian philosopher of language and phenomenologist of culture Mikhail Bakhtin. He borrowed the term from Einstein's theory of relativity, but used it metaphorically and as an essential metric unit in his theory of meaning in language and literature. In Bakhtin's words, chronotope is:

the intrinsic connectedness of temporal and spatial relationships that are artistically expressed in literature. [...] it expresses the inseparability of space and time (time as the fourth dimension of space). We understand the chronotope as a formally constitutive 
category of literature [...]. In the literary artistic chronotope, spatial and temporal indicators are fused into one carefully thought-out, concrete whole. Time, as it were, thickens, takes on flesh, becomes artistically visible; likewise, space becomes charged and responsive to the movements of time, plot and history. This intersection of axes and fusion of indicators characterises the artistic chronotope. The chronotope in literature has an intrinsic generic significance. It can even be said that it is precisely the chronotope that defines genre and generic distinctions, for in literature the primary category in the chronotope is time. The chronotope as a formally constitutive category determines to a significant degree the image of man in literature as well. The image of man is always intrinsically chronotopic. (Bakhtin, 1981, 84-85)

In terms of spatial configuration, the novelistic world of Chachanski's novel is situated in a border zone, among people living along the Ottoman border in Macedonia. Thus, its novelistic world is articulated as a world in between, a world between worlds, an inter-world. This world is populated by the nations who are in between, the in-between kind of nations, the internations. In the novel, this world is called 'mistletoe' [imela, in Macedonian] or 'nausea' [machnina, in Macedonian] (12), representing the Macedonian ontological and phenomenological unrest. The water (in the lake, the river, the wells, and The Wave) stands as a parable for eternal evil (or chaos), which rhythmically renews itself and rises every half-century. The inhabitants of the Christian and the Muslim villages in this border zone live in harmony, united in their shared poverty and language ('both the Christians and the Turks are as one! Balkan people!', 157). They suffer at the hands of the same enemy-the Kachak/Arnaut bandits, ${ }^{6}$ who signify the role that the great powers have in the region by employing their finances in either instigating peace/order or war/disorder. The villagers are represented as mirroring the stereotypical Balkan mélange of honey and mud.

Partially influenced by Bakhtin's metalinguistics (also called 'translinguistics' in Todorov, 1984), the father of cultural semiotics, the Soviet

${ }^{6} \mathrm{TN}$ : Kachaks (derived from the Turkish kaçmak for 'outlaw') is a term used for the Albanian bandits active in the late 19th and early 20th century in northern Albania, Montenegro, Kosovo, and Macedonia, and later as a term for the militias of Albanian revolutionary organisations against the Kingdom of Serbia Kingdom of Yugoslavia, called the 'Kaçak movement' (Bideleux and Jeffries, 2007, 522). Originally, Arnauts was the Ottoman Turkish ethnonym used to denote Albanians, regardless of their religious affiliations. It came from the Byzantine Greek term Arvanites, 'derived from the original name Alvanitis

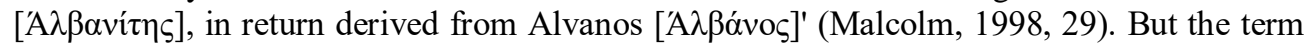
was also used for the Albanian mercenaries in the Ottoman army, as well as for the Albanian bandits from the late 19th and early 20th century, so it remained to have a pejorative denotation among the Balkan Slavic population. 
semiotician Juri M. Lotman also writes extensively on the semiotic and symbolic dimension of the artistically constructed space in literature (Lotman, 1977, 218), and he pays particular attention to the border as a spatial and semiotic category:

In this case, the boundary becomes the most important topological feature of space. The boundary divides the entire space of the text into two mutually non-intersecting subspaces. Its basic property is impenetrability. The way in which the boundary divides the text is one of its essential characteristics (Lotman, 1977, 229-230).

The simplest and most fundamental case is when the space of a text is divided by some boundary into two parts and each character belongs to one of them. But more complex situations are possible too in which different characters not only belong to different spatial areas but are associated with different, occasionally incompatible, types of spatial division (Lotman, 1977, 231).

In Chachanski's novel, the case is of the more complex type, and the characters are living on the very border, having internalised the incompatible spatial and symbolical divisions associated with that border.

In his cult 1984 essay 'On the Semiosphere', when defining his term semiosphere - the semiotic space, outside of which semiosis cannot existLotman goes into detail to make the parallel between the mediatory function of the border in the literary and the cultural semiosphere:

The border of semiotic space is the most important functional and structural position, giving substance to its semiotic mechanism. The border is a bilingual mechanism, translating external communications into the internal language of the semiosphere and vice versa. [...] The function of any border - from the membrane of a living cell to the biosphere as a film (according to Vernadsky) covering our planet, to the delimitation of the semiosphere - comes down to a limitation of penetration, filtering and the transformative processing of the external into the internal. (Lotman, 2005, 210)

Culture not only creates its internal organisation, but also its own type of external disorganisation. Antiquity constructs its "barbarians", and "consciousness"-"subconsciousness". It is irrelevant that these "barbarians", firstly, might possess a significantly more ancient culture, $[. .$.$] Nevertheless, antique civilisation may only regard itself as$ culturally intact through the construction of this allegedly unitary "barbarian" world, the main sign of which was the lack of a common language with the culture of antique civilisation. External structures, distributed on that side of the semiotic boundary, are presumed to be non-structures. (Lotman, 2005, 212-213) 
The boundary has another function in the semiosphere: it is the area of accelerated semiotic processes, which always flow more actively on the periphery of cultural environments, seeking to affix them to the core structures, with a view to displacing them. (Lotman, 2005, 212)

All the above qualifications of the border/boundary of semiotic space perfectly describe Chachanski's border zone.

Lotman's views on cultural semiotics largely influenced the views of the Tartu-Moscow School of Semiotics. His followers developed an interrelated interpretation of the semiotics of cultural history and the semiotics of culture, even translating textual chronotopes into cultural ones and contemplating a chronotopical theory of culture (Torop, 2017, 330). Boris A. Uspenskij, for instance, used the complementarity between time and space in the analysis of historical phenomena. His thought was implicitly chronotopical, and for him, cultural history was, by default, a semiotics of cultural history (Uspenskij, 1996; Torop, 2017, 331). These cultural semiotic theories shed light on the immense symbolical potency of the border in Chachanski's novelistic world. The border is definitely one of the paradigmatic chronotopes of Macedonian history and culture.

In terms of temporal configuration, the other important characteristic of the novel's chronotope is that it is also on the border-line of imaginary and real. In this sense, the novel is magical realist. The ethnically, religiously, and culturally diverse villagers live along the shoreline of the same lake (Lake Ohrid), along the banks of the same river (the Black Drim), and along the sides of the same mountain (Mount Lundzana). Lake Ohrid and the Black Drim River [Crn Drim or Crn Drin] are real and existing hydronyms in Macedonia, but Mount Lundzana is not a real mountain or oronym, although the referred geographical area is very mountainous. Mount Lundzana is the spiritus loci of the novel, its imaginary chronotope. Its name is coined from the verb lundzaan archaic Slavic word for moving about without purpose [to roam, to wander] - that retained its poetic lunar euphony. The villages of Drimeni and Ortakol are not existing villages, but somewhat legendary toponyms from the geographical area surrounding the city of Struga. Ortakol was once used as a term for the Middle Debarca region/Middle River region [Srednorechie], while Drimeni was the Old City of Struga on the left bank of the river Black Drim. According to legend, the Old City remains can still be seen under the river waters. The novel conforms to several imaginary space-time categories: Drimeni, Ortakol, Lundzana, The Wave, The Dream, The Book, and The Stories. The real and the imaginary places in the novel are intertwined just like the real (historical) time and the imaginary time (fiction, oral history, folklore, the sacred texts). The historical time when the events in the novel take place can be identified based on the clues about Sultan Abdul Hamid the First and Ali Pasha of Yanina, as well as the great census carried out in Rumelia and 
Macedonia. Abdul Hamid was in power from 1774 to 1789, while Ali Pasha became the Pasha ${ }^{7}$ for the Yanina region [Pashalik of Yanina] in 1788. Therefore, the novel refers to historical events that had taken place in 1788 and 1789.

The characteristics of the novel's chronotope are so important to this novelistic universe that they are reflected in its characters as well. First of all, the characters in the novel are-likewise-in part historical projections, in part imaginary constructions. They constantly keep entering and exiting the stories and the dream. At this stage, it is important to mention the two gold prospectors, the infatuated diggers and dreamers, Sinan The Turk and Trajle Brchan. They are figures of repentant-converts [pişman, converts who change their mind] and caricatures that point out the tragicomic side to conversion. The story around the two gold prospectors forms a kind of a novel-within-anovel, which is a borderline novel from the viewpoint of its genre and from the viewpoint of its semiotic, and philosophical aspects. But from the semantic and structural viewpoint, this story-within-a-story functions as the mise-enabîme story for the entire novel. The gold prospectors are a tragicomic variant of the history of Macedonian identity. The author transforms (converts) the two banal diggers into surreal guards of the lore of the Macedonian folk - the gold of the rich Macedonian oral tradition - and that is why they are part of the opening and the ending framework of the novel, the framework story (Avramovska, 2004). These two characters stand on the thin line that separates the real from the imaginary and the ephemeral from the eternal in the magicalrealist setting. They are seemingly a Macedonian version of Don Quixote, but in fact, they are an authentic form of tragicomic saviours of the people. In the novel, they decide to give away the found gold coins by leaving them at the thresholds of the Macedonian houses, determined to save the people from dying off. Once they find the stone of thunder (the gold), they symbolically rise to heaven and enter its divine book. The fantastic and magical semantic surplus is merely the prerequisite for being included in the book of history.

The key figure-the ethos $)^{8}$ - of conversion in the novel The Book of Heavens is Adnan Pasha [Adnan Paşa], a Janissary soldier and a high-ranking Ghazi in the Ottoman Empire, ${ }^{9}$ formerly a Macedonian boy from the village

${ }^{7} \mathrm{TN}$ : Pasha [Paşa] is a title for a provincial governor or another high official of the Ottoman Empire, a civil or military officer or authority.

${ }^{8} \mathrm{TN}$ : In reference to Aristotle's differentiation between character (ethos) and plot (mythos) in his Poetics, but also in the broader sense of the Antique Greek word $\tilde{\eta} \theta 0 \varsigma$, as the guiding beliefs, values, or ideals that characterise a community, nation, or ideology.

${ }^{9}$ TN: For Janissaries, see footnote 2. The Ottomans used 'ghazi' as a honourific title to designate a warrior in the religious military conquests of the Islamic Ottoman Empire against the Christian Byzantine Empire. The Arabic term ghāzī (raider) originally referred to an individual who participates in ghazw (military expeditions or raiding), but after the emergence of Islam, it took on new connotations of religious warfare (warriors of the Islamic faith). The 
of Drimeni. At one place, the novel hints to the possibility that his Macedonian name may have been Angel [which means angel] (19); while the etymological meaning of the name Adnan is settler [the one who stays and abides] and is connected to the legendary figure of the expansion of the Arabian Islamic world. ${ }^{10}$ Chachanski's Adnan Pasha is a historical figure who was turned into legend, but the opposite can also be claimed, that he is a legend who was transformed into a historical figure. The attempt to reconstruct the story of Adnan Pasha imposes the necessity to reconstruct the story of the entire novel and the necessity to overlook the narrative currents that are connected to some very important secondary characters. That story, simplified and reduced to its referential biographic minimum, would look like this:

Adnan Pasha is born into an impoverished Macedonian family. He has a father who works as a wagoner [arabadzhija, from the Turkish arabaci], ${ }^{11}$ a mother called Yana, a grandfather Avram, and an uncle on his mother's side Dimitar. He spends his childhood in his native village, surrounded by his family - a familiar world of tradition and customs, poverty and love. It is believed that he carries the strength of two people since he had 'stolen' the strength of his twin-brother. After his father and grandfather are killed by the Albanian mercenaries Arnauts and his mother is kidnapped while he is a mere infant, he becomes an orphan and is looked after by his uncles on his mother's side. This event remains deeply rooted in his memory. His recollections of the tragic massacre from his youth are given in the chapter titled 'Carte Blanche' ['Carta Bianca'] (200-225). In spite of the tragedy, the chapter title underlines that the main character is hereby given carte blanche, he is given the authority and complete freedom to do whatever he thinks is right and to fill in the blanks as he sees fit. Namely, when Adnan-back in the day when his name was Angel - is 10 or 12 years old, he is abducted from his home and sent to join the Janissaries. He is educated in the best of colleges and becomes a part of the Ottoman Turkish military and intellectual elite. Then, he is sent into battles and wars, such as the battle at Bansu in the war with the French, where he is heavily wounded, and only a miracle saves his life. At that point of his life, at

Ottomans used it for their conquests and especially for the frontier warriors against Byzantium. (The Editors of Encyclopaedia Britannica, 2019)

${ }^{10} \mathrm{TN}$ : The etymological meaning of the name Adnan (from Arabic: عدنان, 'Adnān) is 'settler', from the Semitic root ' $d n$, which means 'to stay, to abide'. It is a masculine name common in the Muslim World since its first bearer (one of the ancestors of Prophet Muhammad) was the father of all Arabs of the north of Arabia, a legendary figure of both preIslamic and Islamic mythology, but especially of the expansion of the Arabian Islamic world. (Hanks et al, 2016, 17)

11 TN: Krste Chachanski uses a lot of the adopted Turkish vocabulary, which is characteristic of the Macedonian language and culture at the time the novel takes place and is illustrative of the ambiguous bi-cultural identity of the main character. Most of the culturally specific vocabulary is explained in brackets or footnotes in this translation. 
the age of 21, in spite of having the choice of living anywhere in the Ottoman Empire, he chooses 'the border' and his native village Drimeni on the shores of Lake Ohrid. So, when he gets the opportunity to choose a place where he would spend the rest of his life and live as a free man, he chooses his native Balkan periphery, removed far away from the centre of the Empire, and its wilderness forsaken even by God. And when he gets the opportunity to choose what he would do with the rest of his life and what sense he would give to it, he chooses to build two palaces [sarays], one in his native village Drimeni, and another one near the Lake Ohrid source of the Black Drim River, the saray of his dreams. So, he chooses to come back and build a home for himself. He even manages to find his mother and to grant her a place of honour in the hierarchy of the saray, calling her the Great Mother. He marries Jasmine, an Armenian woman from Thessaloniki, whose family died in a fire when their home was burnt down. ${ }^{12}$ Previously, in his youth, he fell in love with Angelina, who died at childbirth. Their son is raised in a monastery and educated by the monks as a lyricist and a professional scrivener [yazici]. When the son turns about twenty, Adnan Pasha summons him to the saray and employs him as his scrivener, to write his book of destiny (his biography, his memoirs) through dictation. When he comes to Adnan Pasha's saray, the scrivener makes love to Adnan Pasha's wife, although he is in love with the beautiful Grozda Seltina (who dies strangled at the hands of Adnan Pasha's arch-rival Ismail Bey from Debar). In a way, the son and the father, the subject and the master, share the same secrets to attain their kinship in blood and spirit. They believe in the same God, they share the bed of the same woman, and they write the same book. Before Adnan Pasha leaves his saray on the Drim River for the last time - as he is trying not to get caught by the Turkish armed guards [kavas], who are after him for deserting and running off without paying his dues [hazine] $^{13}$ — he only takes the golden 'sword-mizrak' [sword-long spear] from his secret room. But he also leaves behind the icon of Jesus Christ on the eastern wall, with a lit vigil oil lamp and a keepsake box decorated with pearls [sedef], at the bottom of which 'the clear lake water sleeps' (243). He dies, holding hands with his son, with the words 'Lord, all was nothing' (240).

These are the basic contours of the narrative of The Book of Heavens, although it does not end here, for many other stories take place in the novelistic

${ }^{12}$ TN: Probably a reference to the Hamidian massacres of Armenians in the mid-1890s after the Russo-Turkish War, and of the later Massacre of Armenians in the Battle of Marash (1920) during the Franco-Turkish Wars. Some Armenians found refuge in Greece and the surrounding territories, precisely after the Hamidian massacres.

13 TN: The borrowed Turkish word hazine [hazna and kazna in Macedonian] is an interesting ambivalent choice here, since in both Turkish and Russian it means treasure and treasury (most probably with an Iranian origin), but during the Ottoman rule, in all the Balkan Slavic languages it started to mean punishment and infringement fee/penalty. 
chronotope, thus making it possible to read the novel as a narrative mise-enabîme.

Adnan Pasha is a prototype figure of the Janissary convert from the Macedonian geographical area. Here is one description of the feeling of being violently torn away from his family after the kidnapping:

The past has such a hold on him! It was clenched on a piece of meat in his mind, for he was a child, a nursling, and the image would not unhook, the hold would not lessen. In it, he is searching out the outlines of that great hope, but it takes him into unfamiliar territory, with strange men. He is lined up with other children whose words do not resemble his own, but each one of them looks like the next, an entire row of crew-cut, runny-nosed, frown-faced, and ragged boys who do not understand anything that is being said. They are being fed opulently, and then they enter some sort of a large chamber [oda], where again, there is standing in lines, in formations, tulumba desserts, and a prayer. Each day is a new piece of meat, a bloody piece which still smells of an open wound and blood, but it heals with time, for he accustoms himself and starts answering when they call out the name of Adnan! At first, he doesn't want to, but it is his name, his meat... (34)

Still, he is also the Janissary archetype model, which is why this Macedonian Janissary version is so suggestive. Educated in the spirit of the Ottoman Turkish values, he protects those values and serves The Tsarigrad Porte. ${ }^{14}$

However, he is torn inside and split in two by the unrecoverable schism between what he had been as a child and what he had become as a man. It is not like he is living parallel lives, but rather the conflicting life of a split personality, of a schismatic ethos. Adnan Pasha continues to be a child and to dream his Christian dream, even though he never stops adhering to Islam or being a high-ranking officer of The Tsarigrad Porte. Deeply attached to his native identity matrix, yet formally and publicly loyal to the adopted one, he uses mimicry, which leads to the creation of a third personality that is mysterious and mythical. This personality is structured as an intertext from the textures of the two proto-characters: the Turkish Janissary Adnan and the Macedonian child Angel. The first figure is the successful and respectable Ottoman Muslim settler/abider who was unknowingly forced into conversion, and the second figure is the Orthodox Christian angel who is disadvantaged

$14 \mathrm{TN}$ : In Western diplomacy between the 16th and the 18th century, the Imperial Gate [Bâb-1 Hümâyûn] that leads to the outermost courtyard of Topkapi Palace in Constantinopletoday's Istanbul, then called Tsarigrad ['the city of the tsar'] in all the Slavic languages - was known as the Sublime Porte and High Porte [Bāb-1 Ālī], Ottoman Porte, or simply The Porte (The Editors of Encyclopaedia Britannica, 2012). It was used as a synecdochic metonym for the central government of the Ottoman Empire. 
and subjugated in the Ottoman Empire. In the novel, the appearance of a third resulting personality is only foreshadowed by the mysterious appearances of the character of Black George [crni Gjorgjija]. The occurrences of this figure correspond with the long and secretive absences of Adnan Pasha when no one knows where he is going or what kind of mission he is pursuing. In the absence of living witnesses, the novel calls upon the 'sword-mizrak' as the proof that connects Adnan Pasha to Black George, thereby suggesting that Adnan Pasha is the legendary Drimeni $\operatorname{Sirdar}^{15}$ (the third figure) who is seen as a kind of a reincarnation of the Christian martyr St. George. The 'sword-mizrak' was forged by the blood of the hero and it is the symbolic semantic pillar that merges the story of Adnan Pasha with the story of the legendary figure of the Christian military saint, Saint George (159). The sword even seems to be called mizrak in reference to St. George's steel-tipped lance, with which he slew the dragon. ${ }^{16}$ According to legend, St. George slew the blood-thirsty dragon of the city of Silene (Libya) with his lance, saved the daughter of the king, and gave away his reward to the poor, so the citizens all decided to be baptised and to become Christian. According to his hagiographies, he was a Roman soldier with Cappadocian Greek origin who was sentenced to death for not giving up his Christian faith. His martyr death by decapitation on the 23rd of April in the year 303 triggered about forty thousand Roman pagans to convert to Christianity, including the Empress Alexandra of Rome (De Voragine, 1995, 238). Just like St. George, upon his death, Adnan Pasha transforms himself into the metaphysical protector of the religion of the Macedonian people-as a novelistic parable for all Eastern Orthodox Christians, but also of the Macedonian people per se.

Before his very death, Adnan Pasha renounces The Porte. He dies as George [Gjorgjija] the Sirdar. But, it could be argued that he only renounces the forcefully applied Ottoman identity by wilfully re-converting to Christianity and by reclaiming his allegiance to his native people. In some way, Adnan Pasha's allegiance to the Tsarigrad Porte could be seen as ongoing

15 TN: In English, the Indian term 'sirdar' (or the variant 'sardar') is used to translate the Turkish word serdar that is used here. The terms probably have the same origin and they designate the figure of a high ranking commander, a foreman on a respectable position, a person of high rank (such as a hereditary noble), or, as in this case, a warrior leader, a herochieftain.

${ }^{16} \mathrm{TN}$ : In the book, the sword is called 'mech-mazhdrak' in Macedonian. The first part means sword in Macedonian, while the other comes from the Turkish word mizrak, which means long spear, or pointy pike. This mizrak part may refer to a steel pointy tip of the sword, but it seems even more likely that it is a reference to St. George's steel-tipped lance. The Ottoman Janissaries had specific, highly crafted arms in different periods, but their signature yataghan Turkish swords were not long, they were more like short sabres, though their pointy tip was indeed made from steel. This sword is more like a one-handed or two-handed long-sword, and it is described as decorated, golden, and forged by his blood. 
but reinterpreted as a new-found allegiance to the syncretic cultural semiotics of Constantinople. As a hero of the people, he sets them free by setting an example with his wilful choice of religion, just like St. George, or even like St. Constantine. Although the Porte was the symbol of the Ottoman Empire at the time, that gate had the same meaning for the former Byzantine Empire before the Ottoman conquest (as did several other ceremonial and triumphal gates, like the Golden Gate). Until the 13th century, the capital city of Constantinople was the largest and wealthiest city in Europe and a syncretic Mediterranean centre of culture and education, known as Second Rome, New Rome, Basileuousa/Queen of Cities, and Megalopolis/the Great City (Harris, 2007, 24). And interestingly enough, Constantinople was founded by the Roman Emperor Constantine I (272-337 AD), known as St. Constantine in the Christian faith, who is the most famous voluntary Christian convert. First of all, he was the Roman Emperor who stopped the persecution of Christians and proclaimed official status for the Christian religion in the Roman Empire (with the Edict of Milan in 313 AD), but then, he also converted to Christianity on his deathbed himself. In spite of being reigned by three different Empires (Roman, Byzantine, and Ottoman), the capital's Roman nameConstantinople_-was kept until 1923. The Russian philosopher and Slavic literary and cultural scholar Sergei Sergeevich Averintsev was especially interested in these transitional and synthetic cultural modes of the Byzantine and the Orthodox Christian cultures and of culture in general. He also thought that the history of Christianity (unlike that of Islam) remained 'on the border of languages and civilisations' (Averintsev, 2017, 10). But, he was essentially interested in the ways that culture itself is always in a process of transition, in spite of futile political actions to constrain it (Epstein, 2017).

Although the novel suddenly reveals the strong connection between the Drimeni Sirdar and the two Christian saints St. George and St. Constantine, during the entire novel Chachanski is systematically and suggestively building the discordant triangular relationship between Angel, Adnan, and Black George [Gjorgjija] - three characters in one, or one split into three. Angel's birth story - that he had a twin brother who died at birth and whose strength he 'stole' and incorporated to be strong as two people - can now be reiterated on Adnan. Adnan can be seen as two people in one, as incorporating in himself his 'dead' twin brother Angel's identity and strength, in spite of being in a constant battle with him. The third character Black George [Gjorgjija] the Sirdar can be seen as the resulting character from that internal battle, the one who wins and is born as one. However, this complex and conflicting inner dynamism results with a tragic outcome: the internal struggle and the external circumstances are so devastating and uncompromising that the third character has to die upon revealing himself. The only optimism is left for the people affected by his actions, those that could find meaning in his sacrifice and 
follow his example of making a wilful choice in order to live a life that is not schismatic. Undoubtedly, the complex liminal identity of Adnan Pasha stands as a parable of the Macedonian tragically multiplied, split, assimilated, and persecuted identity. Furthermore, this theme projects itself spectrally on every formal aspect of this novel — on the multiplication of its narration, characters, language, space, time, story, and genre - thereby positioning the novel on the very edge between reality and fantasy. This liminality of identity is the centre of gravity in Chachanski's novel and it is the basis of its Magical Realism.

Lotman explains this exact fragile liminal cultural identity in the context of cultural semiotics:

So, for example, when the semiosphere identifies itself with the assimilated "cultural" space, and the world which is external to itselfwith the realm of chaotic disorganised elements - then the spatial distribution of semiotic forms takes the following shape in a variety of cases: a person who, by virtue of particular talent (magicians) or type of employment (blacksmith, miller, executioner), belongs to two worlds, operates as a kind of interpreter, settling in the territorial periphery, on the boundary of cultural and mythological space, whilst the sanctuary of "culture" confines itself to the deified world situated at the centre. [...] All great empires, bordered by nomads, whether "steppe" or "barbarians", settled on their borders members of those same tribes of nomads or "barbarians", hiring them to protect the borders. These settlers formed a zone of cultural bilingualism, ensuring semiotic contacts between two worlds. Areas of multiple cultural meanings carry out the very same function on the boundaries of the semiosphere: town, trade route and other areas forming a kind of creolisation of semiotic structures. [...] However, what must also be taken into account is that if (from the point of view of an immanent mechanism) the boundary unites two spheres of semiosis, then from the point of view of semiotic self-knowledge (self-description on a metalevel) in a given semiosphere, it divides them. To realise itself in a cultural-semiotic sense means a realisation of its specific character, in terms of its opposition to other spheres. This serves to accentuate absolutely those features by which a given sphere is outlined. At different historical moments in the development of the semiosphere, one or other aspects may dominate, suppressing or fully neutralising the other. (Lotman, 2005, 211-212)

Just like the wandering inbetweeners of Mount Lunzana, Adnan Pasha is allowed to settle on the border only to act as 'an interpreter' between the two cultural semiospheres, so he feels that he is uniting them on one level but his own self-knowledge is divided. 
The term liminality entered psychology through anthropology (Turner, 1969), where it referred to the middle stage of ritual: 'a relatively brief period when ritual participants stand at a threshold between the old way of being and the new', when they are 'stripped of their social status and experience a sense of ambiguity or disorientation' (Enders, 2015). But in recent psychological literature, research shows that the same liminality is a common daily experience for individuals who struggle with multiple identities (biracial, multiethnic, genderqueer, bisexual, and/or intersex). They experience the same ambiguity and social disorientation by living in the border zones between two or more opposed socially acceptable identities: 'In a world that prefers binary identity, those whose identity lives in this in-between space feel pressure to claim one end of the polarity and reject the other' (Enders, 2015). However, it is believed that rather than 'being a transitional space, the liminal is, for these individuals, a permanent home' (Enders, 2015). They develop permanent liminality in their identity, which is characterised by ambiguity, bridge-building ability, awareness of boundaries, and a sense of fluidity (Enders, 2011, 44-51). If embraced, this permanent state of liminality can be seen as very positive (Alsultany, 2002; Anzaldúa, 2002; Hill, 2010; Enders, 2011):

Identity must be reconceptualised so that we can speak our own identities as we live and interpret them in multiple contexts. (Alsultany, 2002, 109)

These 'border crossers' (Watkins \& Shulman, 2010, 171) allow for new dialogues by allowing more diversity of perspectives. [...] By resting the locus of identity at the threshold of opposites and not in the identities themselves - what I am referring to as liminal identityallows multiethnic individuals not only more stability in their sense of self but also a platform for transformation. [...] By embracing liminality and discovering others with similar struggles, these individuals can develop a positive understanding of their identities and can at least be seen and appreciated in all their complexity by society at large. [...] By holding dualities simultaneously, the person creates a bridge wherein the borders between 'our' and 'theirs' can be crossed. (Enders, 2015)

It is up to the readers to decide whether the liminal identity of Adnan Pasha and the villagers of Mount Lundzana, as a prototype of the Macedonian liminal identity, can be interpreted as tragically split or as positively complex and dialogic, as a platform for transformation and stability.

When writing his 1934 essay 'Discourse in the Novel' [Slovo v romane] (Bakhtin, 1981), Mikhail Bakhtin saw that utterance/language-use/discourse is also liminal and fundamentally dialogic: 'a border phenomenon', it 'takes place between speakers, and is, therefore, drenched in social factors', and is 
'on the border of what is said and what is not said' (Holquist, 2002, 61). Having in mind all the past, present, and future addressees, the superaddressees, audiences, and alterity in general, Bakhtin introduced many terms to describe the presence and use of the speech of others in one's own speech: 'vnenahodimost' (exterior perspective, another's point of view, 'exotopy'), 'another's word/speech' ('word/speech of the other'), 'alien word/speech', 'hybrid construction', 'double-voiced' (later 'multi-voiced' and 'polyphonic') utterance/word/speech/discourse, and 'heteroglossia' ('other-languagedness', 'raznorechie'). He elevated the term heteroglossia into a specific narrative category, especially in the novelistic discourse. According to him, the novelistic author performs a particular syncretic expression of social heteroglossia, the originality being in the combination, not the elements. (Robinson, 2011). But to him, language is liminal and dialogical precisely because the human individual (the self), human existence (life), and even the world (objects) are fundamentally liminal, relational, and dialogic. He sees the world as a 'symposium', the individual as an 'inter-subject', and culture as an open and never-ending 'dialogue of cultures'. As a philosophical principle, 'dialogism' refers to the inherent relational and dynamic characteristic of being in a continual, manifold, and open dialogue and interaction:

To be means to communicate. [...] To be means to be for another, and through the other, for oneself. A person has no internal sovereign territory, he is wholly and always on the boundary; looking inside himself, he looks into the eyes of another or with the eyes of another. [...] I receive my name from another, and this name exists for the other. (Bakhtin, 1984, 287)

Seen through Bakhtin's dialogism, Adnan Pasha's identity (the Macedonian identity) fits the archetype of the dialogic human condition itself, which is liminal, relational, and dynamic. Also, the inception of the dialogic, liminal, and plural identity of Adnan Pasha is connected to the dialogic, liminal, and plural narrative form of the novel, and this is the setting in which the discourse about the conversion of Christians on Macedonian territory is constituted as well.

\section{The dialogic narrative contextualisation of bi-religious conversion and liminal identity in Krste Chachanski's novel The Book of Heavens:}

The Ottoman Empire ruled in Macedonia from the mid-fourteenth century to 1912 (Sugar, 1977, 53-54). During that time, the Islamisation of the Christian population in Macedonia had taken various forms: individual or collective conversions, violent or willing conversions, and conversions with or without a decree. Also, the conversion to Islam of the Christian and nonMuslim population in the Ottoman Empire meant a conversion of the nonTurkish population into Turkish population, which is why its synonymous 
references Turkification [also called Turkicisation and Turkisation; in Turkish, Türkleştirme] and Ottomanisation have a more popular use. So, in many ways, the conversion to Islam was a multi-directional and plural process. Thus, the researchers feel free to use its plural form-conversions-instead of its singular form, when speaking of Islamisation throughout the Ottoman Empire. Chachanski's novel evokes many aspects and types of these conversions: the conversion of the Janissaries (a specific type of a violent, religious, and ethnic conversion of young boys); the collective conversion of entire villages or families (violent conversion, usually mandated by a decree as a form of sanction due to a prior rebellion); willing conversion (for career advancement, property acquisition, safety, marriage, or other pragmatic purposes); repentant [pişman] conversion (when the converts who were once Islamised and Turkified re-convert back to being Christian and Macedonian again); bireligious or vacant conversion (when the conversion is only formally performed, but the converts retain their affiliation to the previous religion or to both religions); religious mimicry (when the converts only mimic aspects of their religiousness instead of believing in them); and gradual Islamisation (influenced by systematic economic pressures during the five-hundred-year processes of assimilation and acculturation). Still, the dominant model of conversion in this novel is the model of bi-religious or vacant conversion and affiliation, which is a result of the disparity between the politically correct and incorrect discourses. Namely, large portions of the Islamised population would publically practice Muslim rites, but privately and in secret, they would practice the Christian rites:

Even the few who accepted the new faith, secretly light the vigil oil lamp before their house icons at home and plant basil. (130) ${ }^{17}$

This model could be found throughout all of the categories of the Islamised population - with the Janissaries and with others who were Islamised by force, as well as with those who willingly chose to convert. That is how the dual and liminal religious, linguistic, and ethnic identity of the converts was being created, i.e., how the instability of the conversions originated, and how the identity of the Christians - and in this context, of the Macedonians-was becoming more complex and plural.

Master Adnan Pasha [Adnan Paşa efendi] is the prototype of a bireligious convert. Publically, he is a Muslim, but at home, in his secret roomwhich becomes semiotically charged as an essential, symbolic, and sacral

17 TN: Praying in front of and facing home icons with a lit vigil oil lamp is practiced in Orthodox Christianity. Similarly, planting basil for the Elevation of the Holy Cross is an Orthodox Christian tradition celebrated on the April 20th, honouring the way Jesus' Crucifixion Cross was re-discovered in 326 AD by Empress Helene, Emperor Constantine's mother, at the exact place where he had been crucified and where many basil plants were flowering. She had named the plant basil ( $\beta \alpha \sigma \imath \lambda$ ıó), which means 'of the King'. 
space (Lotman, 2006, 187-228) - he is praying before the icon of Jesus Christ. He bows to one god in public, while he worships the other in solitude. The bireligious convert has a public and a secret life, a life for the others and a life for himself. He is a split personality and he deserves understanding. It is regarded that the largest number of Islamised Christian households in the geographical area of Macedonia kept their Christian icons of Jesus, the Virgin Mother, or other Christian household saints for decades, even centuries. When religious conversion reached massive dimensions and became the Empire's strategic priority, bi-religious affiliation took the form of a deep human tragedy among the Christians. The novel reminds us of the stereotypical Turkish proverb that 'A Macedonian cannot make a good Turk'. Although faith is a strictly private matter, it was divided up as manifest religion and latent religion, as a religion for the state and a religion for the self, as an obligatory religion and a desired religion, and as a commendable social practice and an uncommendable family tradition. The bi-religious affiliation was a public secret in the society (a publically acknowledged secret). Therefore, the 'public secret' motto becomes one of the dominant narrative techniques in the novel The Book of Heavens. 'I knew that he knew' (227), says the scrivener when he tells us that Adnan Pasha knows the truth about him, namely, that he-the scrivener, his yazici, his subject, and his son-and Jasmine, the Pasha's wife, are in love. 'I am not who I am', Jasmine tells Adnan Pasha, to which he replies, 'No one can be that. But, you are what you are.' (228). Here, he is not only alluding to religion but also to other aspects of one's identity (emotional, ethnic, blood-related, sexual, gender, social, ideologically-political, racial, etc.).

As a bi-religious man, Adnan Pasha the Janissary ceaselessly manoeuvres to survive within his schismatic existence. His conscious mind is uniting two opposing religious and traditional matrices, therefore it is under a constant attack by his conscience. Adnan Pasha undermines himself constantly with the force of his own Wave - the wave of his own memory. On the one hand, it digs the ground underneath him for the sin of being separated from his people, and on the other, for the sin of becoming a renegade from the powers he now serves. His home (the space), his family (loved ones), his language, his name, his religion (the prayer from page 24), his customs, and his oral traditions - his entire former ' $\mathrm{I}$ ' is the source of his anxieties, of his depressive and melancholic states, and of his mysterious absences. Therefore, Adnan Pasha has to disappear so that the Sirdar George [Gjorgjija] can appear.

One of the most impressive dialogues in the novel is the one between Adnan Pasha and the monk Father Eustace. When Andan Pasha asks the monk whether he is happy, and the monk replies without hesitation that he feels 'so good in his soul' (p. 36), the novel makes an implicit paradoxical comparison that the pasha is unhappy, although he has all the wealth and power one can 
imagine. The monk is blissful, in spite of living in misery and threat, only because he has his own God, his enlightenment, and his undivided being. The monk's name is very aptly chosen here to invoke the third important Christian saint in the novel. St. Eustace was an early Christian martyr, who is still celebrated in Eastern Orthodox Christianity and can be seen as a similar figure to St. Constantine the Great (they have even been depicted together). ${ }^{18}$ They were both soldiers and voluntary Christian converts who were steadfast and invariable in their chosen faith, while Adnan Pasha is struggling to find the balance between the two confronted sides to which he feels loyal. So, Adnan Pasha always finds ways to help the Christians, while carrying out the Sultan's decrees at the same time. He always finds a way to be merciful to the commoners [the raya, the non-Muslim subjects of the Ottoman Empire], while having to enact the imperial edicts (firmans [ferman]) issued from the capital. The other face of Macedonian people's memory is projected in the insomnia that Adnan Pasha suffers from. The novel's intertextual irony suggests remembering and never-forgetting with the message 'Do not sleep people, wake up!'. ${ }^{19}$ The more he loses his own sleep, the more he enters the dreams of the people, the folk legends, the Christian Book of Heavens. This transfer of Adnan Pasha-into the dream of the people, through his insomniaelevates him into a symbol of the will for preserving Macedonian identity.

Adnan Pasha acts on his belief that the impossible is possible. He has the traits of a character in an Ancient Greek tragedy who is defending a higher ethical and ethnic cause at the cost of his/her life. Also, by his suffering to do good for both the Ottoman state and the Christian community, in some way, he projects the basic Christian principle of the 'cathartic power of suffering' or

18 TN: St. Eustace, too, is said to have been a Roman general from Cappadocia (serving under the emperor Trajan), who converted to Christianity upon seeing the crucifixion cross between the antlers of a stag that he was hunting. Upon his baptism, he changed his name

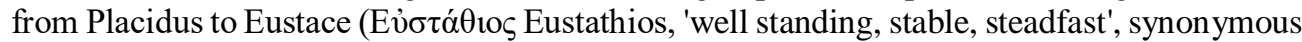
to the Latin name Constans, Constantius, Constantinus). He, too, is revered as a hunter saint and a soldier saint, depicted on frescoes on a white horse with a spear and military apparel. His legend also incorporates a story similar to the story of Job, since, after his conversion, his faith was direly tested with the loss of wealth and with the abduction of his wife and children, but he regained his prestige and his loved ones by never losing faith. Still, upon refusing to make a pagan sacrifice, he and his family were sentenced to a martyr death (by roasting in the bronze bull statue) for their choice of faith. (The Editors of Encyclopaedia Britannica, 2013)

${ }^{19} \mathrm{TN}$ : This is an allusion to the twentieth-century folk song 'Macedonian people' on the massacre of Macedonian villagers after the Ilinden Uprising in 1903, which begins with the following three stanzas:

Macedonian people, | what are your ideals? |Enough, wake up, | come to your senses, don't sleep. || You don't know who and what you are, | others don't know about you. | It's a big shame for you | not to know yourself. || They beheaded women and children | in the village of Zagorichani, | but before the Turkish army, | you dropped your weapons. [...] (Macedonian Folk Songs, 2009) 
martyrdom (Averintsev, 2017, 16). For instance, he would rather die than alienate a part of his country's territory. He refuses to 'make a deal with the Devil' and sell the Drim River to Ismail Bey [beg - the title of an Ottoman nobleman, landlord, chief]. Although he is a convert himself, he does not trade with his country's natural and cultural wealth: 'That which belongs to everyone is not for sale', he says to Ismail Bey (p. 29). For him, the land is not to be given or sold at any price, for it is priceless. This reasoning may be explained with his personal quest for moral and righteousness, but it may also be connected to his previous faith. According to Averintsev's literary and cultural explorations, Christian Orthodoxy focuses on the divine nature of material forms and nature is not seen as an object of human manipulation, but as holy and inseparable from the spirit (Averintsev, 1998). Regardless of the background, this ethical pillar stabilises in Adnan Pasha everything that was shaken in his early childhood-his connection with his people, with his religion, with his language, with his culture. Through his humanism, as the highest form of moral that is devoid of ethnic limitations, he restitutes himself into a strong figure of the Macedonian survival and a figure of the Macedonian connection to their land (soil, earth, nature, geography, climate, territory, and country). Thus, Adnan Pasha-the uprooted one, the representative of the Janissary Diaspora-becomes the symbol of finding a home in the love for one's homeland. This new perspective gives meaning to other elements in the novel and transforms them into parabolic constituents of the novelistic world: his yearning to conquer the Wave/Evil and to save the coastal villages; his taming of the Wave with the force and the wisdom of the village masons; his castle [saray] raised over the source of the river in the lake (perhaps, conquering, controlling, and taming the Water/Evil/Chaos); his view from the castle on the lake as a view that gives life a meaning; his will to rebuild the monastery in the village of Granche on its old foundations (as it usually happens in Macedonia: the new is built on top of the demolished old ruins); his escapes that are necessary for him to become the other one, George [Gjorgjija] the Sirdar, who-much like Ailing Dojchin ${ }^{20}$ in the epic poetry from Struga - is defending Macedonia from the Black Arab; his death that everyone refuses to believe in ('They still say that he is alive and that he is travelling across the sky with his golden spear [mizrak] before nightfall!', on page 243); his revenge over Rizah Fota the Seyman, who killed his father and abducted his mother Yana; his banishment of the Kachaks who abducted mothers, women, and children, and who were setting fires on villages and

${ }^{20} \mathrm{TN}$ : Ailing Dojchin [Bolen Dojchin] is a hero in South Slavic epic poetry who has been ill and bedridden for nine years, but rises to fight for his people and his sister's honour. In spite of his illness, his strength is superhuman and so great that he defeats the foreign landlord, the Black Arab, who imposes unfair daily taxes to the people in goods and young maids. Then, he dies in peace. (For more on Ailing Dojchin and the Black Arab, see: Kulavkova, 2009). 
homes in Macedonia; his secret rituals of transformation, fatherhood, and love catharsis; as well as his deep need to leave a trace in literature and in language as an ontological need to write about himself and to make peace between his two languages (his mother language that he was alienated from, and the foreign language of his education that he adopted as his own). The bi-cultural, liminal, and dialogic language in this novel could be a subject for a new analysis itself, but Bakhtin's words describe all the depth of its psychological, social, and literary aspects:

Language is not a neutral medium [...] it is populatedoverpopulated - with the intentions of others. [...] As a living, socioideological concrete thing, as a heteroglot opinion, language, for the individual consciousness, lies on the borderline between oneself and the other [...] The word in language is half someone else's. It becomes one's "own" only when the speaker populates it with his own intentions, his own accent, when he appropriates the word, adapting it to his own semantic and expressive intention. (Bakhtin, 1981, 294)

At this point of the analysis, the researchers would like to point out another psychological theory that was significantly influenced by Bakhtin's dialogism and is of great importance in the context of Chachanski's novelthe Dialogical Self Theory (DST), founded and developed by the Dutch psychologist Hubert Hermans since the 1990s. Hermans sees the human self as psychologically dialogical: 'a dynamic multiplicity of I-positions, in the landscape of the mind, intertwined as this mind is with the minds of other people' (Hermans, 2002, 147). He compares its functioning to the dynamics of conversation and the social dynamics of exchange and domination (oppositions, conflicts, negotiations, cooperation, and coalitions between the I-positions). This approach developed its methodology around the mind's ability to imagine the different positions of participants in an internal dialogue:

Here, a plurality of independent, unmerged voices are seen as having the capacity to enter into dialogical relationships with each other, forging a self that is characterised by a meeting of othernesses within time as well as across it. (Cooper and Hermans, 2007, 307)

This inner identity plurality of the individual is called 'Self-otherness'. DST proved that the potentiality for an internal diversity and alterity of the self can be very successful in psychotherapy if people are taught how they 'might encounter their own self-otherness' in 'the most psychologically beneficial form', and 'with respect and willingness to honour the enigmatic, uncontrollable, and seemingly alien aspects of our being' (Cooper and Hermans, 2007, 313). DST was especially useful in regard to (deconstructivist and postcolonial) cultural psychology and in alleviating relations between the Self and the cultural Other, since 'otherness - understood as that which is alien, strange and radically different from the "self" — can be experienced 
within one's own being' (Cooper and Hermans, 2007, 306). In this paper, it could be argued that Adnan Pasha goes alone through the process of accepting his cultural othernesses and his own inner self-otherness in a very painful way, and he sincerely tries to integrate his two separate identities with respect and honour. Furthermore, it could be argued that, in determining his choice of action at the end of the novel, Adnan Pasha goes through the process of Ricoeur's tripartite course of ethical deliberation, which vouches for the thorough ethical integrity of his dialogical self:

In short, the trajectory of the self's ethical deliberation involves a tripartite course, which begins with the self directing its actions toward the good by posing an ethical aim; faced with a reality that conflicts with its achieving this aim, the self evaluates its actions in light of the norms of its tradition; finally, when there is no norm that guides unambiguously, the self critically returns to its ethical aim in order to choose its course of action. Ricoeur's theory thus exemplifies a version of self that is thoroughly ethical even in its private deliberations, and is at the same time capable of choosing its own path in a world of others. (Ellis and Stam, 2010, 429-430)

Canadian psychologists Ellis and Stam (2010) aim to supplement DST by incorporating the self's ethical deliberation from the book Oneself as Another (1992 [1990]) by the French philosopher, hermeneutic phenomenologist, and narrative theorist Paul Ricoeur. By identifying the narrative quality of identity and by adding the category of accountability to its story, they claim that Ricoeur explains how the self chooses its course of action and remains to be an entity that is plural and dialogic, rather than dispersing into ambiguousness (Ellis and Stam, 2010, 428-9).

\section{Conclusion}

The epic narrative of the Macedonian Islamised Christians and of their attempt not to forget their previous and native religious tradition is a dramatic attempt not to forget their native identity and culture. 'Considering culture as the long-term memory of the community' and 'a mechanism for organising and preserving information in the consciousness of the community' (Lotman and Uspenskij, 1978, 214-5), and viewing how text 'fulfils the function of a collective cultural memory' (Lotman, 1988, 55), both Lotman and Uspenskij underlined the importance of the selection of facts during the processes of hierarchy, remembering, and forgetting in regard to cultural memory (Lotman and Uspenskij, 1978, 215-6). Similarly, in his book Memory, History, Forgetting, Paul Ricoeur writes about 'mémoire empêchée' [prevented memory] and about the 'resistance to forgetting' when analysing cultural and historical memory $(2000,183)$. It is truly a skill to live the life of a convert in conditions of constant internal conflict and external social despise, mockery, 
and isolation, to live in an eternal equilibrium of simulation until memory extinguishes completely and ashes fall on top of the story. Only after several generations pass, the new religion will become a matter of choice and free will (an accepted identity), the internal resistance and angst will calm down and the soul will be able to find peace. Therefore, the term unrest seems most appropriate to name the border-zone world of the novel, which mirrors the liminal Macedonian ethnic and religious universe. Religion is the stone of temptation for the Macedonians. ${ }^{21}$ The separation from religious traditions has always been a slow process for Macedonians. Such was the process of their separating from the pagan rituals after their christening, and such was the process of their separating from Orthodox Christianity after their Islamisation. Arguably, it could even be claimed that many of the pagan rituals and symbolic thinking were retained within the Orthodox Christian and the Muslim religious traditions (like the Great Mother remnants, embraced by Adnan Pasha in the novel). Probably, the memory of the traditions that are tied to religion runs so deep that it may be resurrected again, including as an urge to return to the roots - in this case, an urge for a repeated Christianisation. Hence, religious memory is a key factor for the conservation and the renewal of the traditions of any people.

That which Adnan Pasha symbolically communicates through his scrivener-son is the immortality of folk legends and collective memory. Adnan Pasha's memoirs are not an ordinary personal testamentary record, but the Macedonian national testament. Krste Chachanski's narrative about Adnan Pasha is a parable for the Macedonian national narrative, for the Macedonian memory, for the Macedonian songs of lamentation-'the sad songs of his people, filled with history and pain' (Chachanski, 2000, 14) - and for the Macedonian walk on the Via Dolorosa of conversion. ${ }^{22}$ Conversion is a Macedonian historical constant, it is a form of discontinuity that is repetitive and becomes an unusual traumatised continuity. It is always followed by dark

${ }^{21} \mathrm{TN}$ : The 'stone of temptation' is a stone that is enshrined in the Monastery of Quarantal, on which Jesus Christ is said to have sat to pray during his forty days in the wilderness. It is particularly associated with his first temptation in Mt 4:3, when "The tempter came to Him and said, "If You are the Son of God, tell these stones to become bread."', to which Christ gave the reply, 'It is written, "Man does not live on bread alone, but on every word that comes from the mouth of God."' In Macedonian, this phrase 'stone of temptation' is used devoid of its Christian origin, and it means anything that presents a crucial temptation, but depending on a person's determination, strength, and faith, it can become either a stepping stone or a stumbling stone.

${ }^{22}$ TN: Via Dolorosa, the Way of the Cross, the Way of Suffering/Grief, and the Way/Walk of Pain are all names for the path that Christ reputably took while carrying his cross from the sentencing to the Crucifixion. Walking the Via Dolorosa with its 14 Stations of the Cross is a Christian pilgrimage route on Easter, but in a symbolical sense, the phrase means enduring immense hardship for a greater purpose and reward. 
periods and dark places of memory, which are written into the history and the collective memory as problematic semantic cracks, but are repeatedly actualised when it is necessary to revive the negation of Macedonian identity. Perhaps one of the biggest cancerous wounds in Macedonian national history is the series of religious, ethnic, and linguistic conversions, accompanied by banishments, terror, migrations, and assimilation. The practice of convertism is deeply reflected in the variability of the name of the people (ethnonyms), of the places (toponyms), of religions, even of the name of the territory and the state of Macedonia.

But conversion also implies a transformation of consciousness (Kulavkova, 2017), and in the case of binary or plural affiliations of one's identity, the transformation becomes very complex, hybrid, liminal, and dialogic. The cultural figure of the Other fluctuates in Adnan Pasha's character: at one time the Other is the Ottoman Turk, and at other times it is the Macedonian Slavic Christian. For his personality and existence to become liminal, he has to develop a fluctuating notion of Otherness. He simply accepts both identities: on the one hand, the newly-acquired, Ottoman, and Muslim identity, and on the other hand, his native, Macedonian, and Orthodox Christian identity. The former identity is publicly accepted, though its forceful acquisition is hidden. The latter identity is accepted secretly and discretely, due to his emotional and mental resistance to forget his home, which is symbolically understood as his primary identity. He internalises both his Others/Othernesses in his Self-otherness, then he attests his ethical aim of being an ethical warrior in the light of the moral norms of both conflicting traditions, and he critically comes back to being the ethical warrior of his choosing. By accepting both identities, he develops an extraordinary capacity for humanity and responsibility toward both communities. Hopefully, the Macedonian liminal reality can breed more humanity, respect, and mutual understanding for the dialogic concept of identity in today's circumstances, as well.

Once again, the new Macedonian novel set forth the enigma of the insufficiently researched and inappropriately understood Macedonian book of conversion of the distant and not-so-distant past, but unfortunately, of the present as well. For the Macedonians, the book of conversion is an open and unfinished book of destiny, which keeps on writing itself. To this day, convertism is a lesson that the Macedonian people have not learned well. Apparently, repetition is not the mother of knowledge (mater studiorum) since humanity keeps on repeating the same colossal mistakes throughout its history. The repetition of the same mistakes is a lesson in Macedonian tragism, as well. The researchers have resigned themselves to conclude that conversion is the Macedonian way to survive, it is a template for the palimpsest of Macedonian identity: erasing one alphabet to inscribe another, suppressing 
one religious and linguistic tradition to introduce another, marginalising one culture to enthrone another. As if there were a lack of an ontological ecospace; as if there were a surplus of memory space or a need for ethnic contamination. The Macedonian identity space is shared by people affiliated with various civilizational, cultural, and religious codices. The reading of the Macedonian book of history requires a perfecting of the mnemotechnic methods, the reconstructive methods, and the methods of the poetics of immanence. On the one hand, a conversion is a form of migration, and on the other, migration furnishes the occasion for conversion. To conclude, the conversion and the migration of the Macedonian people are, in fact, the two faces of the same destiny (and of the same geopolitical strategy). And the Macedonians need to dedicate greater attention to reading their book of history, since to them, it is also their book of Genesis.

Conversion, memory, and literature form an image of the world that should not be ignored by the new cultural strategies about the Balkans and Macedonia, even more so since the truth about Macedonia is still a part of the archives, and more often than not, it remains either undeciphered or tendentiously deciphered. The historical and the mythic knowledge about the Macedonians have not crystallised enough yet, the distance from them is either minimal or maximal, and the un/exclusivity over the historic, territorial, and cultural space is disharmoniously distributed, so that Macedonians do not have their own, generally accepted historical episteme (Kulavkova, 2006b). Thereby, today, the stability of the Macedonian identity is at risk, as well as the legal status of the Macedonian identity - an institution which has been subjected to systematic denials for centuries — not so much due to an absence of an archenarrative, as much as due to conditions of confusion of narratives and narrators. At a certain time, the denial of the identity of a people will certainly be placed in the function of denying the state of that people. History attests to the fact that whenever there were periods of stabilisation of the Macedonian identity, there were also conflict situations whose aim was to thwart the existence of Macedonian statehood. The methodology of this thwarting usually actualises the category of identity, the thesis for an absence of historical evidence supporting the particularity of Macedonian identity (or rather, the alleged existence of evidence in the opposite direction), and the thesis for an artificial construction of identity (language, people), while simultaneously instigating the processes of internal disunity (Serbo-mania, Bulgaro-philia, Hellenisation, Albanianisation), migration, Diaspora, assimilation/acculturation, and conversion of the Macedonian people - that is to say, all the procedures of territorial fragmentation ('Balkanisation'), mediated by the great powers. Krste Chachanski's novel The Book of Heavens contributes to a much more nuanced and complex understanding not only of 
the Macedonian identity per se but also of the nature of human identity in general.

\section{References:}

1. Aleksov, Bojan. (2006). Poturica gori od Turčina: Srpski istoričari o verskim preobraćenjima [An Assimilated Turk is Worse Than a Real Turk: Religious Conversion in Serbian Historiography]. Historiografski vidici II, Forum Bosnae, no. 35: 22-47. Saraevo: Međunarodni forum Bosna. Available in Serbian at: http://postjugo.filg.uj.edu.pl/baza/files/100/vjerski-mitovi.pdf

2. Alsultany, E. (2002). Los Intersticios: Recasting Moving Selves. In G. E. Anazaldúa, \& A. Keating (Eds.), This Bridge We Call Home: Radical Visions for Transformation (pp. 106-110). New York, NY: Routledge.

3. Anzaldúa, G. E. (2002). (Un)natural bridges, (Un)safe places. In G. E. Anzaldúa, \& A. Keating (Eds.), This Bridge We Call Home: Radical visions for transformation (pp. 1-5). New York: Routledge.

4. Averintsev, S. S. (1998). Ritorika i istoki evrope ̌̌skŏ literaturnŏ tradiciji [The Rhetorics and the Eastern European Literary Tradition]. Moscow: Jazyki russkoj kultury.

5. Averintsev, S. S. (2017). Hrišćanstvo u XX veku [Christianity in the 20th century]. Beograd: Otachnik/Bernar.

6. Avramovska, N. (2004). Vo vitelot na derealizacijata (dnoto na makedonskata drama) [In the Whirlwind of De-Realization: the Bottom of Macedonian Drama]. Skopje: Kultura.

7. Bakhtin, M. M. (1981). The Dialogic Imagination: Four Essays. Ed. Michael Holquist. Trans. Caryl Emerson and Michael Holquist. Austin, TX: University of Texas Press.

8. Bakhtin, M. M. (1984). Problems of Dostoyevski's Poetics. Ed. and trans. Caryl Emerson. Manchester: University of Manchester Press.

9. Bakhtin, M. M. (1986). Speech Genres and Other Late Essays. Ed. by C. Emerson and M. Holquist. Trans. Vern W. McGee. Austin, TX: University of Texas Press.

10. Brailsford, H. N. (2002). Makedonija - Nejzinite narodi i nejzinata idnina. Skopje: Kultura [1906. Macedonia: Its Races and its Future. London: Methuen \& Co. Available at: http://www.promacedonia.org/en/hb/index.html].

11. Chachanski, K. (2000). Kniga na neboto [The Book of Heavens]. Skopje: Kultura.

12. Cooper, M. and Hermans, H. (2007). Honouring Self-otherness: Alterity and the Intrapersonal. In Livia Mathias Simao and Jaan Valsiner (Eds.), Otherness in Question: Labyrinths of the Self (305- 
315). Charlotte, North Carolina: Information Age Publishing. Available

at: https://www.researchgate.net/publication/279534635_Honouring_Sel f-otherness_Alterity_and_the_Intrapersonal

13. Currie, M., ed. (2001). Metafiction. New York: Longman Group Publishing.

14. De Voragine, J. (1995). Life of St. George. The Golden Legend. Princeton, NJ: Princeton University Press. Available at: https://catholicsaints.info/golden-legend-life-of-saint-george/

15. Eco, U. (2002). Intertekstualna ironija i nivoi tumačenja. $O$ književnosti. Beograd: Narodna knjiga-Alfa. [(2002). Sulla Litteratura. Milan: Bompiani; (2005). Intertextual Irony and Levels of Reading. On Literature. Trans. by Martin L. McLaughlin. New York: Mariner Books, 212-235.]

16. Ellis, B. D. and Stam, H. J. (2010). Addressing the Other in Dialogue: Ricoeur and the Ethical Dimensions of the Dialogical Self. Theory \& Psychology 20(3):420-435. Ontario: University of Guelph. Available at:https://www.researchgate.net/publication/247743922_Addressing_ the_Other_in_Dialogue_Ricoeur_and_the_Ethical_Dimensions_of_th e_Dialogical_Self

17. Enders, A. (2011). Finding wholeness: Understanding liminality through my experience as a biracial woman (Master's thesis). Pacifica Graduate Institute, Carpinteria, CA. Available at https://www.academia.edu/11441449/FINDING_WHOLENESS_UN DERSTANDING_LIMINALITY_THROUGH_MY_EXPERIENCE _AS_A_BIRACIAL_WOMAN.

18. Enders, A. (July 18, 2015). What is Liminal Identity? Liminal Identity: Identity in the In-between. Retrieved from http://liminalidentity.com/what-is-liminal-identity/. Accessed on May 21, 2019.

19. Epstein, M. (2007). Averintsev, Sergei. In DeBlasio, A. and Mikhail Epstein (eds.), Filosofia: An Encyclopaedia of Russian Thought. [Online]. Available at: http://filosofia.dickinson.edu/encyclopedia/sergei-averintsev/.

20. Harris, J. (2007). Constantinople: Capital of Byzantium. New York: Continuum USA.

21. Hermans, H. J. M. (2002). The dialogical self as a society of mind. Theory \& Psychology, 12 (2): 147-160. Ontario: University of Guelph. Available at: https://journals.sagepub.com/doi/abs/10.1177/0959354302122001 
22. Hill, R. C. (2010). Liminal identity to wholeness. Jung Journal: Culture \& Psyche, 4, 16-30. Available at https://www.tandfonline.com/doi/abs/10.1525/jung.2010.4.2.16

23. Holquist, M. (2002, 2nd ed. [1990]). Dialogism: Bakhtin and His World. London and New York: Routledge.

24. Hobsbawm, E. J. (1990). Nations and Nationalism since 1780. Cambridge: Cambridge University Press.

25. Kulavkova, K. (2000). From Simplification to Paronomasia: The ReSemantization of the Paradigm of the Turk in Macedonian Literature. In Nedret Kuran Burcoglu (Ed.), The Image of the Turk in Europe from the Declaration of the Republic in 1923 to the 1990s (pp. 295-310). Istanbul: The Isis Press.

26. Kulavkova, K. (2006a). Balkanska slika na svetot [Balkan Image of the World]. In Katica Kulavkova (Ed.), Balkanska slika na svetot/Balkan Image of the World (pp. 15-47). Skopje: Macedonian Academy of Sciences and Arts (MASA).

27. Kulavkova, K. (2006b). Hermenevtika na identiteti [Hermeneutics of Identities]. Skopje: Makedonska Riznica.

28. Kulavkova, K. (2009). Preface: An Arabesque for the Black Arab, Bolen Dojcin and White Angelina. In Katica Kulavkova (Ed.), Interpretations, vol. 3, The Black Arab as a Figure of Memory (xixviii). Skopje: Macedonian Academy of Sciences and Arts (MASA). Available at http://manu.edu.mk/wpcontent/uploads/2017/03/Interpretations-Volume-3-Version-2_Black-ARAB.pdf

29. Kulavkova, K. (2017). Secularism and post-secularism: The two great religious and civilizational shifts. In Markus Krienke - Elmar Kuhn (eds.). Two indispensable topoi of interreligious dialogue / New "languages" far beyond the dead ends of dialogue (139-152). Vienna: Verlag TENE QUOD BENE, Editio academiae book series of the European Academy of Sciences and Arts and of the Alma Mater Europaea Salzburg Vol. 2. Available at https://www.amazon.de/dp/3950448616.

30. Lotman, J. M. (1977). The Problem of Artistic Space. The Structure of the Artistic Text. Trans. by Ronald Vroon. No. 7 Ann Arbor. MI: University of Michigan, pp. 217-231. Available at: https://monoskop.org/images/3/3e/Lotman_Jurij_The_Structure_of_t he_Artistic_Text_1977.pdf [(1970). Struktura khudozhestvennogo teksta. Moscow.].

31. Lotman, J. and Uspenskij, B. (1978). On the semiotic mechanism of culture. New Literary History 9 (2): 211-232. 
32. Lotman, Y. M. (1988 [1981]). The semiotics of culture and the concept of a text. Soviet Psychology 26 (3): 52-58. Available at https://www.tandfonline.com/doi/abs/10.2753/RPO10610405260352.

33. Lotman, J. M. (2005). On the Semiosphere. Translated by Wilma Clark. Sign Systems Studies 33(1): 205-229. Available at: https://www.academia.edu/21861844/On_the_Semiosphere_Translati on_. [(1984). O semiosfere. Sign Systems Studies (Trudy po znakovym sistemam) 17: 5-23.]

34. Lotman, J. M. (2006). Simbolichki prostori [Symbolic spaces]. Semiosfera: vo svetovite na mislenjeto [Semiosphere: In the Worlds of Thought]. Translated by Marija Gjorgjieva. Skopje: Tri. [(1990). Universe of the Mind: A Semiotic Theory of Culture. Intr. by Umberto Eco. Bloomington: Indiana University Press.]

35. Mihajlovski, D. (2002). Smrtta na dijakot [The Death of the Wild One]. Skopje: Kaprikornus.

36. Nikolova, O. (2002). Vežbi za Ibn Pajko [Variations on Ibn Pajko]. Skopje: Tri.

37. Racin, K. (2018). Beli Mugri [White Dawns]. Skopje: Ars Lamina publikacii [(1939). Samobor: Dragutin Schpuler.]

38. Ricoeur, P. (1992 [1990]). Oneself as Another. Trans. K. Blamey. Chicago, IL: University of Chicago Press.

39. Ricoeur, P. (2000). La mémoire, l'histoire, l'oubli. Paris: Editions du Seuil.

40. Robinson, A. (July 29, 2011). Bakhtin: Dialogism, Polyphony and Heteroglossia (The Column In Theory). Ceasefire Magazine. Accessed May 30, 2019, available at: https://ceasefiremagazine.co.uk/in-theorybakhtin-1/

41. Sugar, P. F. (1977). Southeastern Europe under Ottoman Rule, 13541804. Seattle: University of Washington Press.

42. Todorov, Tzvetan. (1984 [1981]). Mikhail Bakhtin: The Dialogical Principle. Trans. by Wlad Godzich. Manchester, Minnesota: Manchester University Press/The University of Minnesota Press.

43. Torop, P. (2017). Semiotics of cultural history. Sign Systems Studies 45(3/4): 317-334. Tartu: University of Tartu. Available at: https://www.academia.edu/37461801/Semiotics_of_cultural_history_ Semiotics_of_cultural_history.

44. Turner, V. (1969). The ritual process: Structure and anti-structure. Chicago, IL: Aldine.

45. Uspenskij, B. A. (1996). Semiotika istorii. Semiotika kultury. Moscow: Jazyki russkoj kultury. 
46. Watkins, M., \& Shulman, H. (2010). Toward psychologies of liberation. New York: Palgrave Macmillan.

\section{References for the Translator's Notes:}

1. Aristotle. (1932). Volume 23: Poetics. In Aristotle in 23 volumes. Translated by W.H. Fyfe. London: Harvard University Press. Retrieved from http://www.perseus.tufts.edu/hopper/text?doc=Perseus\%3Atext\%3A1 999.01.0056.

2. Aristotle. (1920). On the Art of Poetry. Translated by Ingram Bywater. Oxford: Clarendon Press. Retrieved from https://archive.org/details/aristotleonarto00aris/page/26.

3. Bideleux, R. and Ian J. (2007). The Balkans: A Post-Communist History. Abingdon: Routledge.

4. Hanks, P., Coates, R. and P. McClure (2016). The Oxford Dictionary of Family Names in Britain and Ireland. OUP Oxford. Retrieved from https://www.oxfordreference.com/view/10.1093/acref/978019967776 4.001.0001/acref-9780199677764 (May 26, 2019).

5. Homer. (1851). The Iliad. Trans. by Theodore Alois Buckley. London: H. G. Bohn.

6. Macedonian Folk Songs. (October 28, 2009). Macedonian People [Narode Makedonski]. $\quad$ Retrieved from https://pesna.org/song.php?id=494

7. Malcolm, N. (1998). Kosovo: A Short History. London: Macmillan.

8. The Editors of Encyclopaedia Britannica. (September 7, 2012). Sublime Porte. Encyclopaedia Britannica. Encyclopaedia Britannica, inc. Retrieved from https://www.britannica.com/topic/Sublime-Porte. Accessed on May 6, 2019.

9. The Editors of Encyclopaedia Britannica. (August 7, 2013). Saint Eustace. Encyclopaedia Britannica. Encyclopaedia Britannica, inc. Retrieved from https://www.britannica.com/biography/Saint-Eustace. Accessed on May 4, 2019

10. The Editors of Encyclopaedia Britannica. (April 24, 2014). Janissary. Encyclopaedia Britannica. Encyclopaedia Britannica, inc. Retrieved from https://www.britannica.com/topic/Janissary-corps. Accessed on March 4, 2019.

11. The Editors of Encyclopaedia Britannica. (August 8, 2019). Ottoman Empire. Encyclopaedia Britannica. Encyclopaedia Britannica, inc. Retrieved from https://www.britannica.com/place/Ottoman-Empire. Accessed on September 10, 2019. 